Nicole Louise Busby

Norwegian University of Science and Technology

DOI: http://dx.doi.org/10.5617/adno.5579

\title{
Comparing first and second language reading: the use of metacognitive strategies among Norwegian university students
}

\begin{abstract}
Metacognitive awareness is one of the key predictors of successful reading, in particular for second language and academic reading. This article presents a study that investigated Norwegian university students' metacognitive awareness when reading academic texts in Norwegian (L1) and English (L2). 316 students answered a questionnaire which included a 30-item survey of reading strategies and self-ratings of reading proficiency in both languages. The analysis reveals a surprisingly similar awareness of reading strategies in L1 and L2. The main differences found were in the use of two specific reading strategies: reading more slowly and using resources such as dictionaries. Despite overall similarities in the approach to $L 1$ and $L 2$ reading, participants rated their own proficiency as much higher in $L 1$ reading than L2. Regression models show significant associations between self-ratings of proficiency and the number and type of reading strategies reported, particularly in the L2, demonstrating that there is an important connection between these. Research on other populations has shown a much higher use of reading strategies in L2. However, the similarity in approaches to $L 1$ and $L 2$ reading among the university students in this study may reflect a higher level of L2 proficiency among these students, as well as high expectations of proficiency, meaning they do not feel a need to use reading strategies for decoding $L 2$ text. Instead, these students may benefit from additional training in the use of higher level reading strategies to improve their comprehension of L2 academic texts.
\end{abstract}

Keywords: metacognitive awareness, academic reading, $L 2$ reading, English as a second language, reading strategies

\section{Sammenligning av første- og andrespråkslesing: bruk av metakognitive strategier blant norske universitetsstudenter}

\section{Sammendrag}

Metakognitiv bevissthet er avgjørende for gode leseferdigheter, spesielt når det gjelder leseferdigheter $i$ andrespråk og akademisk lesing. Denne artikkelen 
presenterer sentrale funn fra en studie som undersøkte norske universitetsstudenters metakognitive bevissthet ved lesing av akademiske tekster på norsk (L1) og engelsk (L2). 316 studenter ble bedt om å fylle ut et spørreskjema med 30 spørsmål om lesestrategier, samt å vurdere egne leseferdigheter i begge språk. Deltakerne viser en overraskende lik bevissthet omkring bruken av lesestrategier i L1 og L2. De største forskjellene som ble funnet, angår bruken av to spesifikke lesestrategier: det å lese sakte og det å bruke ressurser som ordbøker. Til tross for generelle likheter i studentenes tilncerming til lesing $i$ L1 og L2, vurderer deltakerne sine egne leseferdigheter som mye bedre i L1 enn i L2. Regresjonsmodeller viser signifikante sammenhenger mellom egenvurderingen av leseferdigheter og antall og type rapporterte lesestrategier, scrlig i L2, noe som viser at det er en viktig relasjon mellom disse. Forskning på andre populasjoner har vist en mye høyere bruk av lesestrategier i L2. Likheten i tilncerminger til L1- og L2-lesing blant universitetsstudenter i denne studien kan indikere et høyere nivå av L2-leseferdighet blant disse studentene, samt høye forventede ferdigheter, noe som betyr at de ikke føler behov for å bruke lesestrategier for å dekode L2-tekst. I stedet kan disse studentene dra nytte av opplcering i bruk av lesestrategier på mer overordnet nivå for å forbedre forståelsen av L2 akademiske tekster.

Nøkkelord: metakognitiv bevissthet, akademisk lesing, andrespråkslesing, engelsk som andrespråk, lesestrategier

\section{Introduction}

English is the common language of academia, which means that non-native English-speaking university students around the world need to read academic texts in a second language (L2). Reading in L2 is inherently more complex than reading in the first language (L1), because two languages are involved in almost every stage of the process (Koda, 2007). Even for highly proficient L2 users, reading is slower in L2 than L1 (Fraser, 2007; Shaw \& McMillion, 2008), which is thought to be the result of having to stop and "repair" gaps in comprehension (Block, 1992). In spite of these challenges, non-native English speakers at universities around the world are expected to read and understand complex concepts and new ideas in the L2. In order to provide targeted support for these students, researchers need to understand what strategies L2 readers use to overcome these challenges (Mokhtari \& Reichard, 2004). Much research has focused on L2 readers with low proficiency, but less research has been conducted on readers with relatively high proficiency in L2. This study investigates academic reading among Norwegian university students, whose high English proficiency is generally taken for granted (Hellekjær, 2008), to find out how they approach academic reading in a second language. 
Norwegians have some of the highest levels worldwide of English language proficiency among non-native speakers (Bonnet, 2004; Education First, 2017), and they are expected to read and understand academic English texts at university without assistance. In school, however, Norwegian students need to study English from year 1 until year 11, and do not need to pass any English examination or test to be admitted to Norwegian universities, they only need to achieve sufficiently good grades overall (Utdanningsdirektoratet, 2013). In practice, "Norwegian institutions of higher education take for granted that English as a foreign language [...] instruction in upper secondary schools effectively prepares students for the use of English in higher education” (Hellekjær, 2009, p. 199).

There are many reasons why English proficiency levels in Norway are reported to be high. English and Norwegian are both Germanic languages, with many cognates and similar grammar, and most Norwegians are also extensively exposed to English on an everyday basis through the media. Norwegian learners also score high in international tests (Education First, 2017), and English is becoming widely regarded as a second language, rather than a foreign language, in Norway (Graddol \& Meinhof, 1999). However, studies have shown that a large proportion of Norwegian students struggle with English at university (Hellekjær, 2005, 2009). Previous studies have found that two-thirds of Norwegian students about to start university would not meet the English proficiency requirements for entry into English-speaking universities (Hellekjær, 2005) and that Norwegians read academic, but not non-academic, English texts more slowly than native English speakers (Busby, 2015). A lack of English proficiency has also been suggested as contributing to high drop-out rates in the first year of university in other Nordic countries (Berman, 2010). This study aims to investigate whether the strategies they use to cope with L2 reading could explain the discrepancy between high levels of general English proficiency and low scores on measures of academic English reading.

\section{Theoretical background}

Successful L2 reading results from the combination of reading ability and L2 proficiency (Carrell, 1991; Koda, 2007). A number of studies have demonstrated that higher L1 literacy levels are linked to higher L2 literacy levels (e.g. Olsen, 1999; Royer \& Carlo, 1991). Bernhardt's (2011) compensatory model of L2 reading explains that L1 and L2 knowledge interact so that weaknesses in one area may be compensated for by strengths in another. She notes that although the combination of L1 literacy and L2 knowledge have been found to account for around half of the variance in L2 reading success, the other half comprises less easily defined variables such as motivation and use of strategies for reading comprehension. Also, Cummins' (1979) interdependence theory states that academic reading proficiency transfers from L1 to L2 so "that students who have developed literacy in their first language will tend to make stronger 
progress in acquiring literacy in their second language” (Cummins, 2000, p. 173). Various factors have been shown to affect how well this transfer happens. Linguistic distance - the extent to which the L1 and L2 are related - is an important factor in L2 reading development (Grabe, 2009), and being aware of the relatedness of the two languages confers additional benefits (Jiménez, García, \& Pearson, 1995).

One of the most critically important factors for successful reading is metacognitive awareness (Grabe, 1991): the readers' awareness and monitoring of their own comprehension processes while reading (Mokhtari \& Reichard, 2002). Metacognitive awareness enables successful use of reading strategies, broadly defined as "mental plans, techniques, and actions taken while reading" (Mokhtari \& Sheorey, 2002, p. 2), to regulate text comprehension (Mokhtari \& Reichard, 2002). Reading strategies include techniques such as thinking about the topic, looking forward and backward in the text, and undertaking deliberate actions to improve understanding (Mokhtari \& Reichard, 2002; Paris \& Jacobs, 1984). Skilled readers, and those with more experience, have been shown to display high levels of metacognitive awareness (Malcolm, 2009). They tend to plan, make predictions, and observe and monitor their own performance and comprehension more consistently than less experienced readers (Block, 1992; Huang \& Nisbet, 2012; Malcolm, 2009). Studies have also shown a significant link between students' reading ability and their awareness and use of reading strategies while reading (Alhaqbani \& Riazi, 2012; Sheorey \& Mokhtari, 2001; Zhang $\& \mathrm{Wu}, 2009)$. Poor readers are less aware of strategies and how and when to use them (Alderson, 2000).

The use of reading strategies is especially important in L2 reading, where comprehension monitoring plays a vital role (Block, 1992). Research has suggested that effective use of reading strategies can help compensate for a lack of L2 proficiency (Carrell, Pharis, \& Liberto, 1989). Some reading strategies are unique to L2 reading, such as translation and being able to think about information in both languages (Mokhtari \& Reichard, 2002). A survey of reading strategies (SORS), developed by Mokhtari and Sheorey (2002), has been used to measure metacognitive awareness in academic reading (i.e. reading textbooks and other academic material) among native and non-native English-speaking student populations around the world. Studies using this instrument have found that reading strategies are reported to be used at a high rate when reading in L2 (Alhaqbani \& Riazi, 2012; Feng \& Mokhtari, 1998; Malcolm, 2009; Mokhtari \& Reichard, 2004; Sheorey \& Mokhtari, 2001; Zhang \& Wu, 2009), especially when compared to reported strategy use in L1 reading (Alsheikh \& Mokhtari, 2011; Kong, 2006; Mokhtari \& Reichard, 2004; Sheorey \& Mokhtari, 2001).

The choice of reading strategy also appears to be linked to the proficiency of the reader. Less proficient L2 readers may apply fewer higher-order thinking processes while reading, and tend to focus more on word recognition and wordfor-word translation (Auerbach \& Paxton, 1997; Malcolm, 2009). In other 
words, struggling readers may be more motivated to use reading strategies to compensate for a lack of understanding, and benefit from having an obvious link between strategies and task demands (Brevik, 2015). As a consequence, training in the use of metacognitive strategies is most effective when the emphasis is placed on teaching people to become strategic readers, and knowing when to use particular strategies, rather than teaching strategies alone (Anderson, 1991; Grabe, 2004). This suggests that teaching students that problems can arise during reading and that there are strategies to overcome these, can be more important to successful reading than teaching vocabulary or other aspects of language in isolation (Block, 1992). However, as Anderson (1991) points out, a certain minimum level of vocabulary and background knowledge of a topic is required before helpful strategy choices can be made.

Knowing how to communicate in everyday settings is not always the same as being able to read and understand academic language, and reading academic language can be an additional challenge, even in L1, with different vocabulary, phrasing and conventions. Consequently, academic language can pose particular challenges to L2 readers at a tertiary level. Cummins (1979) distinguishes between basic interpersonal communication skills (BICS) used for conversational purposes, and cognitive academic language proficiency (CALP), the ability to understand and express concepts relevant for academic purposes. It has been demonstrated that these types of language develop at different stages of life (e.g. Hakuta, Butler, \& Witt, 2000). Reading strategies are thought to be used to a greater extent when reading academic texts because of the greater cognitive demand (Mokhtari \& Reichard, 2008), and thus a higher level of CALP is required. The complexity of the task further appears to have an effect on strategy choice, with more difficult texts found to prompt a greater use of reading strategies (Feng \& Mokhtari, 1998; Brevik, 2015).

Research into how and when reading strategies are used by proficient readers is important in designing instructions to help less proficient readers (Huang \& Nisbet, 2012; Sheorey \& Mokhtari, 2001). Instruction in metacognitive strategies has been shown to improve reading in children who are learning to read (Paris \& Jacobs, 1984) as well as adult L2 readers (Bannert, Hildebrand, \& Mengelkamp, 2009; Huang \& Nisbet, 2012). It has also been suggested (e.g. Brevik, 2015; Hellekjær, 2008) that inefficient strategy use may be one explanation of the difficulties experienced by Norwegian students when reading in English. The present study therefore aims to find out more about how these students use reading strategies in L2 compared to in L1.

\section{Research questions}

In order to investigate Norwegian students' metacognitive awareness of reading strategies in L1 and L2 academic reading, this study will focus on the following questions: 
1. Do the Norwegian students in this study use different strategies, or use them at different frequencies, when reading in L1 and L2?

2. How does the use of reading strategies by these students compare with previous research on students in other countries?

3. Is there a relationship between metacognitive awareness and self-ratings of reading proficiency for the students in this sample?

4. Does reported reading strategy use differ between first year university students and those with more university study experience?

\section{Methods}

The present quantitative study used a survey to investigate awareness of reading strategies in L1 and L2 among Norwegian university students. The survey was conducted during lecture periods in order to ensure a high participation rate and thereby as representative a sample of the student population as possible. The survey was administered in English. Feedback from pilot testing on native Norwegian speakers confirmed that the wording was comprehensible to the target audience.

The participants in this study were 316 native Norwegian-speaking university students at a Norwegian university who reported not having English as a first language. Participants were recruited from undergraduate classes which had both English and Norwegian language texts on the course reading list to ensure that participants had experience reading academic texts in both L1 and L2. Although this precluded a completely random sample, the classes from which participants were recruited covered a range of subject areas (including psychology, geography, social anthropology, archaeology, and sign language) and amount of time spent at university (from first semester to 4+ years) in order to provide as representative a sample as possible.

The survey used for data collection consisted of items from the Survey of Reading Strategies (SORS) developed by Mokhtari and Sheorey (2002) as well as questions asking participants to rate aspects of their own reading proficiency in both English and Norwegian. The survey can be found in Appendix A. The SORS is a validated survey designed to test metacognitive awareness of reading strategies among L2 readers. It comprises 30 items relating to strategies used while reading academic texts, and participants are asked to rate how often they are aware of using each of these on a 5-point Likert scale. The SORS is adapted from the Metacognitive Awareness of Reading Strategies Inventory developed by Mokhtari and Reichard (2002), which was validated using responses from a large native English-speaking population of high school and university students $(\mathrm{N}=825)$, and shown to be a reliable measure of metacognitive awareness of reading strategies (Cronbach's alpha for the total sample $\alpha=.93$ ). The SORS is designed for use with non-native speakers of English and includes two strategies 
relevant for L2 reading: translating from L2 to L1, and thinking about information in both languages. Responses to each of the items on the SORS are classified as high (mean 3.5 or above), moderate (mean between 2.4 and 3.5), and low usage (mean 2.4 or below).

The items are divided into three subscales: Global, Support and Problem Solving. Global reading strategies (13 items) consist of items relating to the analysis of the text as a whole such as "I think about what I know to help me understand what I read" and "I have a purpose in mind when I read". Support strategies (9 items) are practical strategies used to support understanding, such as using reference materials or underlining important information. Problem Solving strategies (8 items) are oriented around resolving difficulties encountered while reading such as "I try to get back on track when I lose concentration" and "when text becomes difficult, I pay closer attention to what I am reading". These subscales were developed following a series of factor analyses, and were found by Mokhtari and Sheorey (2002) to have Cronbach's alpha coefficients of $\alpha=.92$, .79 and .87 for the Global, Support and Problem Solving subscales respectively.

Two versions of the survey were created for this study: one in which participants were instructed to report their use of reading strategies (the items adapted from the SORS) while reading academic texts in Norwegian and one for academic texts in English. Participants were randomly assigned to either the Norwegian $(N=156)$ or the English $(N=160)$ version of the survey. In the Norwegian version, the two final questions, which were specific to L2 reading, were omitted because participants were being asked about reading in their native language. Therefore, when comparing responses to the two versions of the survey, the first 28 reading strategy items are analysed separately from the last two unless otherwise specified.

The results from the survey give quantitative data indicating the extent of students' metacognitive awareness of reading strategies when reading in L1 and L2. Three main methods were used to analyse the data collected. Descriptive statistics are used to provide an overview of the data and enable comparisons with previous research in other populations. Then, $t$-tests are used to compare means and check whether samples are significantly different from one another. Finally, multiple regression models were used to estimate the effects of reported reading strategy use on self-ratings of proficiency and academic achievement as measured by average ${ }^{1}$ grade. Linear regression is a standard statistical test in reading research, so results are displayed using these models. It could be mentioned that ordinal regression, which is more appropriate for results collected from Likert scales (Chen \& Hughes Jr., 2004), was also conducted and yielded similar results. Model simplification was conducted, but made no

\footnotetext{
${ }^{1}$ Participants were asked "What grades do you usually get at university?" (see Appendix A for details). This may have led to reports of their mode or mean grade, so I have referred to it as 'average' throughout. This should be kept in mind when interpreting the results.
} 
significant difference to the explained variance $\left(\mathrm{R}^{2}\right)$ values. Given that the emphasis is on comparing L1 and L2 reading rather than constructing a model to predict reading outcomes, the full models are presented in order to provide more information.

\section{Results}

The analysis of the survey results will be discussed in two sections: first a comparison of reading strategies used in L1 and L2 reading, and second an investigation of responses in relation to time spent at university (as a proxy for exposure to academic language).

\section{Comparing $L 1$ and $L 2$ reading Self-ratings of proficiency}

In order to meaningfully compare participants' approaches to reading in L1 and L2, it was important to first understand how they perceived their relative reading proficiency in the two languages. All participants were asked to rate their reading ability, speed of reading and ease of understanding on a five-point scale for both English and Norwegian reading.

Table 1. Paired-sample $t$-tests comparing self-rating of aspects of reading proficiency in Norwegian (L1) and English (L2) on a 5-point scale from 1 low to 5 high

\begin{tabular}{llllllll}
\hline & \multicolumn{2}{l}{ Norwegian $(\mathrm{N}=316)$} & & \multicolumn{2}{l}{ English $(\mathrm{N}=316)$} & \multirow{2}{*}{$t(316)$} & $p$-value \\
\cline { 2 - 3 } & $M$ & $S D$ & & $M$ & $S D$ & & \\
\hline Reading ability & 4.67 & 0.56 & & 3.87 & 0.87 & 18.84 & $.000^{*}$ \\
Reading speed & 3.95 & 0.73 & & 3.15 & 0.91 & 16.33 & $.000^{*}$ \\
Ease of understanding & 4.68 & 0.77 & & 3.54 & 1.29 & 16.31 & $.000^{*}$ \\
\hline
\end{tabular}

${ }^{*} p<0.05$

As can be seen in Table 1, participants on average rated all of these aspects of reading proficiency much higher in Norwegian than in English. Paired-sample $t$ tests showed that this difference was highly significant $(p<.001)$ for all three questions (see Table 1), indicating that on average they felt much more proficient at reading in L1 than in L2. However, over a third of the participants rated their reading proficiency for Norwegian and English as equal, while approximately 1\% of the participants rated their English reading proficiency higher than Norwegian for each of the measures.

\section{Reading strategies}

The next step was to compare awareness of reading strategy use in L1 and L2. Mean responses were calculated for the 28 items common to the Norwegian and English versions of the survey and ranked in order of most to least used. The full 
list of strategies, ranked according to frequency of use, can be seen in Appendix $\mathrm{B}$, and the five most frequently used are shown in Table 2.

Table 2. The five most frequently used reading strategies reported for Norwegian (L1) and English (L2) and mean rates of reported use

\begin{tabular}{ll|l}
\hline Reading Strategy & Mean L1 & Mean L2 \\
\hline Adjusting reading speed & 4.11 & 4.19 \\
Trying to stay focused & 4.04 & 4.18 \\
Paying close attention & 4.03 & 4.09 \\
Re-reading difficult text & 3.97 & 4.04 \\
Setting purpose for reading & 3.89 & 3.78 \\
\hline
\end{tabular}

Interestingly, the first five items were the same in the two languages, indicating that there were some reading strategies that participants considered to be very useful in both languages. This also suggests that they did not feel a need to approach reading in L1 and L2 very differently. The number of reading strategies in the high, moderate and low usage categories can be seen in Table 3.

Table 3. Numbers of reading strategy items reported to be used at high, moderate and low rates in L1 and L2 (first 28 items)

\begin{tabular}{lcll}
\hline & High $(\geq 3.5)$ & Moderate & Low $(\leq 2.4)$ \\
\hline Norwegian (L1) & $9(32 \%)$ & $16(57 \%)$ & $3(11 \%)$ \\
English (L2) & $10(36 \%)$ & $18(64 \%)$ & $0(0 \%)$ \\
\hline
\end{tabular}

Table 3 shows a remarkable similarity in the mean reported reading strategy use for L1 and L2 reading. Based on the classification of means in the SORS, nine of the reading strategies were reported to be used at a high rate for L1 reading, and 10 for L2 reading. Only three of the strategies were reported at a low rate for $\mathrm{L} 1$ reading and none were classified in this category for L2 reading.

Next, between-subjects $t$-tests were used to investigate whether there were any significant differences between the number of reading strategies reported for L1 and L2 reading by subscale or for the 28 items in total (Table 4).

Table 4. Results from between-subjects t-tests comparing awareness of reading strategies (on a 5point scale) in L1 and L2 by subscale and overall

\begin{tabular}{|c|c|c|c|c|c|c|}
\hline & \multicolumn{2}{|c|}{ Norwegian $(\mathrm{N}=156)$} & \multicolumn{2}{|c|}{ English $(\mathrm{N}=160)$} & \multirow[t]{2}{*}{$t(316)$} & \multirow[t]{2}{*}{$p$-value } \\
\hline & $M$ & $S D$ & $M$ & $S D$ & & \\
\hline Global & 3.27 & 0.54 & 3.27 & 0.54 & 0.06 & .956 \\
\hline Support & 2.93 & 0.62 & 3.06 & 0.64 & 1.81 & .071 \\
\hline Problem Solving & 3.57 & 0.57 & 3.68 & 0.49 & 1.85 & .064 \\
\hline Overall (28 items) & 3.27 & 0.42 & 3.34 & 0.46 & 1.21 & .228 \\
\hline
\end{tabular}

As shown in Table 4, reading strategy use was only slightly higher for English reading than for Norwegian. Between subjects $t$-tests confirmed that the difference between the overall number of reported reading strategies was not significant between languages $(t=1.21, p=.228)$. Nor were differences by 
language significant when analysed by subscale (Global, Support and Problem Solving), suggesting that the students in this sample did not feel the need to use more reading strategies in L2 reading than in L1.

Between-subjects $t$-tests were also conducted to compare mean reported use of each of the 28 reading strategy items between L1 and L2 to see whether they were reported used at different rates. Analysis revealed that only two of the individual reading strategies were reported to be used at significantly higher levels when reading in English (L2) than in Norwegian (L1): the use of reference materials such as dictionaries $(t=2.62, p=.009)$ and reading slowly and carefully $(t=2.08, p=.039)$. The other reading strategies were not reported at significantly different rates in L1 and L2.

\section{Relationship between reading strategies and self-rated reading proficiency}

Multiple regression models were calculated to investigate whether the self-rated proficiency scores could be predicted based on reported use of reading strategies by subscale. This showed that reported reading strategy use accounted for small but significant amounts of variance in some aspects of Norwegian reading, as can be seen in Table 5, although the models for L1 reading were not good predictors of self-ratings of reading proficiency overall.

Table 5. Multiple regression models: aspects of self-rated reading proficiency in Norwegian (L1) as a function of reading strategies by subscale

\begin{tabular}{|c|c|c|c|c|c|c|}
\hline Iodel 1: self-rated reading & $y$ in & $\mathrm{a} \mathrm{ful}$ & of re & rategies & subsca & \\
\hline & $B$ & SE B & $\beta$ & $t$ & $p$ & $R^{2}$ \\
\hline Model 1 & & & & & $<.001$ & .04 \\
\hline Global strategies & .22 & .11 & .23 & 2.09 & $.038^{*}$ & \\
\hline Support strategies & -.15 & .10 & -.17 & -1.53 & .128 & \\
\hline Problem Solving strategies & .07 & .10 & .08 & 0.72 & .476 & \\
\hline Model 2: self-rated reading & eed in & a func & of reac & trategies & subscal & \\
\hline & $B$ & $S E B$ & $\beta$ & $t$ & $p$ & $R^{2}$ \\
\hline Model 2 & & & & & $<.001$ & .04 \\
\hline Global strategies & .26 & .15 & .18 & 1.67 & .097 & \\
\hline Support strategies & -.05 & .14 & -.04 & -0.33 & .744 & \\
\hline Problem Solving strategies & .08 & .15 & .06 & 0.55 & .585 & \\
\hline Model 3: self-rated ease of $\mathbf{t}$ & derstar & in L1 & functio & eading $s$ & egies b & scale \\
\hline & $B$ & $S E B$ & $\beta$ & $t$ & $p$ & $R^{2}$ \\
\hline Model 3 & & & & & $<.001$ & .05 \\
\hline Global strategies & .29 & .14 & 22 & 2.07 & $.040 *$ & \\
\hline Support strategies & -.09 & .12 & -.08 & -0.70 & .484 & \\
\hline Problem Solving strategies & .06 & .13 & .05 & 0.472 & 638 & \\
\hline
\end{tabular}

${ }^{*} p<0.05$

As seen in Table 5, Global strategies were found to be significantly and positively associated with self-ratings of reading ability $(\beta=.23, p=.038)$ and ease of understanding $(\beta=.22, p=.040)$. This means that participants who 
reported using higher levels of Global reading strategies were significantly more likely to rate their reading ability and ease of understanding as higher. Support strategies and Problem Solving strategies did not contribute significantly to the predictions of any aspect of reading proficiency in Norwegian.

Table 6 shows the results of the models for English reading, i.e. the relationship between self-reported L2 reading proficiency measures and reading strategies by subscale. Reported reading strategy use accounted for slightly more of the variance in the L2 reading proficiency ratings than it did for L1, as reflected by more of the predictors contributing significantly to the models and slightly higher $\mathrm{R}^{2}$ values.

Table 6. Multiple regression models: aspects of self-rated reading proficiency in English (L2) as a function of reading strategies by subscale

Model 4: self-rated reading ability in L2 as a function of reading strategies by subscale

Model 4

$B$ $S E B$

$p$

$<.001$

Global strategies

Support strategies

.41

.16

.26

$-.38 \quad .12$

$-.29$

$.012^{*}$

Problem Solving strategies

.19

.17

.11

2.55

$-3.07$

$.003^{*}$

$1.12 \quad .265$

Model 5: self-rated reading speed in L2 as a function of reading strategies by subscale

Model 5

$B \quad S E B$

Global strategies

Support strategies

.56

Problem Solving strategies

.56
-.37

.18

.19

.32
-.25
.05

$<.001$

09

Model 6: self-rated ease of understanding in L2 as a function of reading strategies by subscale

Model 6 $B$ SE B

Global strategies

Support strategies

Problem Solving strategies

$\begin{array}{rr}.29 & .26 \\ -.33 & .20 \\ .10 & .28\end{array}$

.12

$-.16$

.04
1.32

$-2.71$

0.45

$.007^{*}$

.651

${ }^{*} p<0.05$

As displayed, Global strategies were found to be positively associated with selfratings of reading ability $(\beta=.26, p=.012)$ and reading speed $(\beta=.32, p=$ .002 ), meaning that participants who reported using higher levels of Global reading strategies were significantly more likely to rate their reading ability and reading speed as higher. Support strategies were found to be negatively associated with both reading ability $(\beta=-.29, p=.003)$ and speed $(\beta=-.25, p=$ .007), meaning that those who reported high levels of use of these strategies were significantly more likely to describe their reading as poorer and slower. Problem Solving strategies did not contribute significantly to predictions of any aspect of self-rated reading proficiency. None of the reading strategy subscales were significantly associated with ease of understanding for English. The explained variance for the L2 models is still low, but slightly higher than for the 
L1 models. Stronger associations between reading strategies and ratings of proficiency in English reading than Norwegian reading indicates that use of reading strategies for this sample functions as a stronger predictor of self-rated proficiency in L2 reading than for L1.

In order to investigate further whether awareness of reading strategies might be a predictor of academic achievement, participants were asked to report the average grade they received across all their university classes. This was used as a dependent variable with the reading strategy subscales using multiple regression models (Table 7). Variance in grades could be partly accounted for by reading strategy use in both L1 and L2 reading although, interestingly, different strategies functioned as significant predictors in the two languages.

Table 7. Multiple regression models: average grade as a function of reading strategies (by subscale) in L1 and L2

\begin{tabular}{|c|c|c|c|c|c|c|}
\hline \multicolumn{7}{|c|}{ Model 7: average grade as a function of reading strategies in L1 (Norwegian) } \\
\hline & $B$ & SE B & $\beta$ & $t$ & $p$ & \multirow{5}{*}{$\begin{array}{l}R^{2} \\
.06\end{array}$} \\
\hline Model 7 & & & & & $<.001$ & \\
\hline Global strategies & .35 & .16 & .24 & 2.24 & $.027 *$ & \\
\hline Support strategies & .11 & .14 & .09 & 0.78 & .439 & \\
\hline Problem Solving strategies & -.18 & .15 & -.13 & -1.19 & .238 & \\
\hline \multicolumn{7}{|c|}{ Model 8: average grade as a function of reading strategies in L2 (English) } \\
\hline & $B$ & $S E B$ & $\beta$ & $t$ & $p$ & $R^{2}$ \\
\hline Model 8 & & & & & $<.001$ & .08 \\
\hline Global strategies & .11 & .18 & .07 & .62 & .540 & \\
\hline Support strategies & .39 & .14 & .27 & 2.816 & $.006 *$ & \\
\hline Problem Solving strategies & -.47 & .18 & -.26 & -2.57 & $.011^{*}$ & \\
\hline
\end{tabular}

${ }^{*} p<0.05$

Table 7 shows that awareness of Global reading strategies in Norwegian was a significant predictor of average grade $(\beta=.24, p=.027)$. Awareness of Support strategies in English was significantly and positively associated with average grade $(\beta=.27, p=.006)$, and Problem Solving strategies were negatively associated with grades $(\beta=-.26, p=.011)$. This indicates that the awareness of Support strategies in English reading is associated with higher grades, and also suggests that students who are struggling academically may be using more Problem Solving strategies in their English reading.

\section{Strategies specific to $L 2$ reading}

Items 29 ("When reading, I translate from English into my native language") and 30 ("When reading, I think about the information in both English and my mother tongue") of the SORS relate to strategies specific to second language reading, so only participants who answered the version of the questionnaire that asked about their English language reading were asked these questions. The first of these, translating into L1, was reported at a moderate rate of usage $(M=2.78$, 
$S D=1.38)$ and thinking about information in both languages was reported at a higher rate $(M=3.80, S D=1.22)$.

These reading strategies were also tested as possible predictors of self-rated reading proficiency. Multiple regression modelling demonstrated that both of these items were predictors for self-rated reading proficiency with fairly high and significant correlations. Item 29 was negatively associated with self-rated reading ability $(\beta=-.48, p<.001)$ and reading speed $(\beta=-.49, p<.001)$, meaning participants who were aware of using translation frequently were more likely to rate their English reading ability as poorer and slower. Item 30 was a significant predictor of positive ratings of reading ability $(\beta=.26, p<.001)$ and ease of understanding $(\beta=.15, p=.028)$, indicating that students who reported thinking about information in both languages were more likely to rate their reading ability in English as high and have an easier time understanding English texts.

\section{Relation between academic experience and reading measures}

To investigate whether having more practice at reading academic texts affects reported reading strategy use or perceptions of proficiency, participants were grouped into two categories based on the number of semesters of university they reported having completed at the time of participation. Participants who had completed two or fewer semesters of full-time study were classified as "first year" students $(\mathrm{N}=177)$ and those who had completed more than two semesters were "later year" students $(\mathrm{N}=139)$. Analysis using between-subjects $t$-tests showed no significant differences between the first year and the later year group with regard to levels of reported reading strategies either overall or by subscale. The L2-specific items (questions 29 and 30) did not significantly differ by study experience either.

Next, between-subjects $t$-tests were used to compare average self-ratings of reading proficiency in L1 and L2 between first year and later year students to see whether perceptions of reading proficiency changed as a result of university experience.

Table 8 shows that for Norwegian reading, only reading ability was rated as significantly higher $(\mathrm{t}=-2.58, \mathrm{p}=.01)$ for later year students than first year students. For English reading, later year students rated their reading proficiency significantly higher than first year students on all three measures (see Table 9), indicating that students felt that their reading proficiency in English improved over time. These results imply that academic experience was more strongly associated with self-ratings of reading proficiency in English than in Norwegian reading for this sample, although awareness of reading strategies did not vary significantly in relation to time spent at university. 
Table 8. Results from between-subjects t-tests comparing self-rated reading proficiency (on a 5-point scale) in Norwegian (L1) in first year and later year students

\begin{tabular}{|c|c|c|c|c|c|c|}
\hline & \multicolumn{2}{|c|}{ First year $(\mathrm{N}=177)$} & \multicolumn{2}{|c|}{ Later year $(\mathrm{N}=139)$} & \multirow[t]{2}{*}{$t(316)$} & \multirow[t]{2}{*}{$p$-value } \\
\hline & $M$ & $S D$ & $M$ & $S D$ & & \\
\hline Reading ability & 4.59 & 0.60 & 4.75 & 0.50 & -2.58 & $.010 *$ \\
\hline Reading speed & 3.89 & 0.80 & 4.01 & 0.79 & -1.19 & .231 \\
\hline Ease of understanding & 4.59 & 0.83 & 4.76 & 0.69 & -1.95 & .052 \\
\hline
\end{tabular}

Table 9. Results from between-subjects $t$-tests comparing self-rated reading proficiency (on a 5-point scale) in English (L2) in first year and later year students

\begin{tabular}{|c|c|c|c|c|c|c|}
\hline & \multicolumn{2}{|c|}{ First year $(\mathrm{N}=177)$} & \multicolumn{2}{|c|}{ Later year $(\mathrm{N}=139)$} & \multirow[t]{2}{*}{$t(316)$} & \multirow[t]{2}{*}{$p$-value } \\
\hline & $M$ & $S D$ & $M$ & $S D$ & & \\
\hline Reading ability & 3.74 & 0.93 & 4.00 & 0.78 & -2.73 & $.006 *$ \\
\hline Reading speed & 3.03 & 0.97 & 3.27 & 0.82 & -2.38 & $.018 *$ \\
\hline Ease of understanding & 3.38 & 1.32 & 3.71 & 1.25 & -2.27 & $.023 *$ \\
\hline
\end{tabular}

${ }^{*} p<0.05$

\section{Discussion}

The main finding of this study was that the Norwegian students in this sample reported remarkably similar strategy use for L1 (Norwegian) and L2 (English) academic reading, despite rating their reading proficiency as much higher in L1 than L2. Additionally, the results indicated that metacognitive awareness was more strongly associated with self-rated reading proficiency and academic achievement in L2 than L1, which suggests that strategy use is especially important in L2 reading. Finally, study experience, measured by comparing first year and later year students, showed no significant differences between reported reading strategy use, although self-ratings of L2 reading proficiency were significantly higher among later year students.

\section{Comparing reading strategy use in $\mathrm{L} 1$ and $\mathrm{L} 2$}

On the whole, it appears that Norwegian students approach academic reading in Norwegian and English in a remarkably similar fashion with regard to reading strategy use. There were no significant differences in awareness of reading strategies between L1 and L2 overall or by subscale, and only two of the individual items (reading slowly and carefully, and use of additional resources) were reported at a significantly higher rate when reading in English. Additionally, the five most frequently used reading strategies in Norwegian and English were the same (see Table 2 for details).

Compared with previous research on other populations using the SORS, the Norwegian students completing this survey reported relatively low levels of reading strategy use for L2 reading, with only 10 strategies out of 30 being used at a high rate (mean of 3.5 or above) for reading in English. In comparison, students in Bahrain reported using 19 of the strategies at a high rate when 
reading in L2 (Malcolm, 2009), Chinese students reported using 15 strategies at a high rate (Zhang \& Wu, 2009), Moroccan students reported 15 strategies at a high rate (Mokhtari \& Reichard, 2004), and students reading in Arabic as L2 reported using 18 strategies at a high rate (Alhaqbani \& Riazi, 2012). In contrast, native English-speaking students in the US reported using only eight of the strategies at a high rate when reading in L1 (Mokhtari \& Reichard, 2004; Sheorey \& Mokhtari, 2001). In other words, the use of reading strategies by Norwegian students reading in L2 was more similar to that of American students reading in L1, which most probably reflects their high levels of English proficiency.

Previous studies comparing L1 and L2 reading in other populations have also found significantly higher levels of reported reading strategies for L2, even among highly proficient L2 readers (Alsheikh \& Mokhtari, 2011; Feng \& Mokhtari, 1998; Kong, 2006). The similarities in awareness of reading strategies in L1 and L2 reported by the Norwegian students in the present study could be interpreted as meaning that these students feel equally comfortable reading in both languages, and therefore do not need additional strategies to enable them to cope with L2 reading. However, questions about reading experiences indicated that students felt their reading was significantly slower, and they understood less when reading in English than in Norwegian. It may be that the high expectations of English proficiency associated with the reputation Norwegians have of being "good at English", their high level of conversational English, and the expectations of the universities, mean that these students assume that reading in English should be the same as reading in Norwegian, and therefore they do not adopt additional reading strategies to cope with any difficulties.

\section{Relationships between strategy use and experience, academic performance and self-perceptions of reading proficiency}

Later year students reported their reading ability, reading speed and ease of understanding as significantly higher than first year students did for English reading. For Norwegian reading, only reading ability was reported as significantly higher for later year students, and there were no significant differences in self-reported reading speed or ease of understanding. There did not seem to be an increase in metacognitive awareness associated with university reading experience among these participants. No significant differences were seen in the number of reading strategies used (either overall or by subscale) in first year compared to later year students in either English or Norwegian. This is an interesting contrast to the SORS study conducted on medical students in Bahrain by Malcolm (2009) which found that later year students tended to use many reading strategies at a significantly higher rate than first year students.

Many of the studies finding large differences in L1 and L2 metacognitive awareness have compared reading between English and languages which are linguistically very different from English, such as Arabic or Chinese (Alsheikh 
\& Mokhtari, 2011; Feng \& Mokhtari, 1998; Kong, 2006). Compared to native speakers, Alhaqbani and Riazi (2012) suggest that L2 readers expect to encounter difficulties such as unfamiliar vocabulary or cultural references. The extensive exposure to Anglophone culture and the similarities between English and Norwegian appear to lead to high general proficiency, but perhaps also a false sense of security among Norwegian students (Mahan \& Brevik, 2013).

The present study found a stronger link between metacognitive awareness of reading strategies and self-ratings of reading proficiency for L2 than L1 reading. Average grades were also more strongly associated with reading strategy use in English than Norwegian. This is in line with previous research showing links between metacognitive awareness and reading proficiency (Grabe, 1991) and reading comprehension test scores (Karbalaee Kamran, 2012). This also fits with the idea that reading strategies are particularly important for L2 academic reading (Mokhtari \& Reichard, 2008) and more complex texts (Feng \& Mokhtari, 1998).

It is also interesting to note that awareness of reading strategies was a predictor for self-ratings of proficiency and average grade, but the association was not always positive. Global strategies for English reading were positively associated with self-rated reading ability and speed, but Support strategies were negatively associated with these. Support strategies, which include procedures such as using dictionaries and reading aloud, are less likely to be associated with proficient reading than Global or Problem Solving strategies (Mokhtari \& Reichard, 2002). They are presumably used when readers get stuck and need help with understanding what they are reading. This fits with the study of Norwegian upper-secondary school students which found that poorer readers were motivated to use strategies that helped them to directly improve their reading comprehension when reading English, whereas the better readers tended to use more Global strategies such as selective reading in order to achieve specific goals (Brevik, 2015).

In terms of individual strategies found to differ between L1 and L2, the high reported use of slow and careful reading as a strategy for coping with L2 reading may help to explain results of previous research showing a slower reading rate for Norwegian students reading in English (Busby, 2015; Hellekjær, 2005, 2009). It is even possible that slow and careful reading and having two languages to assist with processing information may lead to better recall of information, and the strategy "thinking about information in both languages" was positively associated with self-reports of reading proficiency. This would fit with Bernhardt's (2011) model in that L1 reading skills may be used to compensate for a lack of L2 proficiency. Without sufficient proficiency in L2, however, the benefits of skills acquired through L1 reading may be "short circuited" and the reader will revert to poorer reading strategies in L2 and consequently poorer comprehension (Clarke, 1980). 
There has been some suggestion (Hellekjær, 2009) that Norwegian students are not well trained to read even in L1 and may be too focused on decoding rather than reading to learn. The Programme for International Student Assessment (PISA) found that Norwegian 15-year-olds scored significantly below the OECD average in L1 reading proficiency (Kjærnsli, Lie, Olsen, \& Roe, 2007), although this has been improving in recent years (PISA, 2016). It has been suggested that these problems are still present among university students, and that they are unable to adjust reading strategies to suit the purpose of the task (Fjeldbraaten, 1999). Therefore, the English reading difficulties found in previous studies (Busby, 2015; Hellekjær, 2005, 2012) and relatively low levels of metacognitive awareness observed in the students in this study may be a reflection of a more general reading problem, and not just an L2 problem.

\section{Limitations}

Caution should be used when directly interpreting results from studies using the SORS, which is designed to measure students' self-awareness rather than actual metacognition. This survey gives an indication of students' awareness of reading strategies, and studies using think-aloud procedures have shown that this does not always equal actual strategy use (Anderson, 1991; Kong, 2006). A survey such as this is also not able to give information about when strategies are used, and research has shown that context is important in understanding strategy use (Alsheikh \& Mokhtari, 2011; Zhang \& Wu, 2009). Furthermore, it has been shown that the selection of appropriate strategies is just as important as the overall number of strategies (Anderson, 1991).

There are also limitations in the extent to which the results from this study are applicable to Norwegian university students more generally, because the participants surveyed were from a limited range of subject areas (mostly humanities) and from only one university. Only students who were present in lectures were surveyed, and this might bias the sample towards students who are more active participants in the classes. It is also important to note that later year students are generally those who have been successful in a university environment, so it may be that they have always had higher levels of metacognitive awareness than those who dropped out. Despite these limitations, this type of survey is nevertheless useful as a comparison to other populations studied in previous research.

\section{Conclusion}

In contrast to research in other countries which found that students employ a greater use of reading strategies when reading academic texts in L2, this study found no significant differences between awareness of reading strategies in L1 and L2 among Norwegian university students. This suggests that these students 
have reached a level of proficiency where reading strategies are not essential for decoding L2 writing, but the lower self-ratings of proficiency in L2 than L1 indicate that these students are still not entirely comfortable with reading in English.

Metacognitive awareness is vital for successful academic reading, particularly in a second language, so further research is needed into whether additional support and training in higher-level reading strategies would be beneficial to these students. Future research should also include actual measures of reading speed and comprehension in L1 and L2 so that these could be compared with data from the self-reports in this study. The more we know about how students read in L2, the more support can be offered to promote skilful academic reading and to improve comprehension.

\section{About the author}

Nicole Louise Busby is a PhD candidate in Linguistics in the Department of Language and Literature at the Norwegian University of Science and Technology (NTNU). Her research interests include second language acquisition, academic language and second language reading.

Institutional affiliation: Department of Language and Literature, Norwegian University of Science and Technology (NTNU), Dragvoll campus, building 5, level 5, NO-7048 Trondheim.

E-mail: nicole.busby@ntnu.no

\section{References}

Alderson, J. C. (2000). Assessing Reading. Cambridge: Cambridge University Press.

Alhaqbani, A., \& Riazi, M. (2012). Metacognitive awareness of reading strategy use in Arabic as a second language. Reading in a Foreign Language, 24(2), 231-255.

Alsheikh, N. O., \& Mokhtari, K. (2011). An examination of the metacognitive reading strategies used by native speakers of Arabic when reading in English and Arabic. English Language Teaching, 4(2), 151-160.

Anderson, N. J. (1991). Individual Differences in Strategy Use in Second Language Reading and Testing. The Modern Language Journal, 75(4), 460-472.

Auerbach, E. R., \& Paxton, D. (1997). "It’s Not the English Thing”: Bringing Reading Research Into the ESL Classroom. TESOL Quarterly, 31(2), 237-261.

Bannert, M., Hildebrand, M., \& Mengelkamp, C. (2009). Effects of a metacognitive support device in learning environments. Computers in Human Behavior, 25(4), 829-835.

Berman, R. (2010). Icelandic university students’ English reading skills. Málfríður, 26(1), $15-18$.

Bernhardt, E. (2011). Understanding advanced second-language reading. New York: Routledge. 
Block, E. L. (1992). See how they read: Comprehension monitoring of L1 and L2 readers. TESOL Quarterly, 16(2), 319-343.

Bonnet, G. (Ed.) (2004). The assessment of pupils' skills in English in eight European countries 2002. The European network of policy makers for the evaluation of educational systems.

Brevik, L. M. (2015). Strategies and shoes: Can we ever have enough? Teaching and using reading comprehension strategies in general and vocational programmes. Scandinavian Journal of Educational Research, 61(1), 76-94.

Busby, N. L. (2015). Too cool for school? Sources of English language acquisition, attitudes, and academic reading ability among Norwegian university students. Master's thesis, Norwegian University of Science and Technology (NTNU), Trondheim, Norway. https://brage.bibsys.no/xmlui/handle/11250/299104

Carrell, P. L. (1991). Second language reading: Reading ability or language proficiency? Applied linguistics, 12(2), 159-179.

Carrell, P. L., Pharis, B. G., \& Liberto, J. C. (1989). Metacognitive strategy training for ESL reading. TESOL Quarterly, 23(4), 647-678.

Chen, C.-K., \& Hughes Jr., J. (2004). Using Ordinal Regression Model to Analyze Student Satisfaction Questionnaires. IR Applications, 1, 1-13.

Clarke, M. A. (1980). The short circuit hypothesis of ESL reading-or when language competence interferes with reading performance. The Modern Language Journal, 64(2), 203-209.

Cummins, J. (1979). Linguistic interdependence and the educational development of bilingual children. Review of Educational Research, 49(2), 222-251.

Cummins, J. (2000). Language, power, and pedagogy: Bilingual children in the crossfire. Clevedon, England: Multilingual Matters.

Education First (2017). English Proficiency Index. Retrieved from http://www.ef.no/epi/regions/europe/norway/

Feng, X., \& Mokhtari, K. (1998). Strategy use by native speakers of Chinese reading easy and difficult texts in English and Chinese. Asian Journal of English Language Teaching, 8, 19-40.

Fjeldbraaten, A.-L. (1999). Undervisning i lærings-og studiestrategier i sammenheng med allmennlærerutdanningens pedagogikkundervisning [Teaching of learning and study strategies in relation to the pedagogical training of general teacher students]. In I. Bråten \& B. S. Olaussen (Eds.), Strategisk læering [Strategic learning] (pp. 122-138). Oslo, Norway: Cappelen.

Fraser, C. A. (2007). Reading rate in L1 Mandarin Chinese and L2 English across five reading tasks. Modern Language Journal, 91, 372-394.

Grabe, W. (1991). Current developments in second language reading research. TESOL Quarterly, 25(3), 375-406.

Grabe, W. (2004). Research on teaching reading. Annual Review of Applied Linguistics, 24, 44-69.

Grabe, W. (2009). Reading in a second language: Moving from theory to practice. Cambridge: Cambridge University Press.

Graddol, D., \& Meinhof, U. H. (1999). English in a Changing World (AILA review 13). Guildford, UK: Biddles Ltd.

Hakuta, K., Butler, Y. G., \& Witt, D. (2000). How long does it take English learners to attain proficiency? University of California Linguistic Minority Research Institute Policy 2000 1. Santa Barbara, CA: University of California-Santa Barbara. 
Hellekjær, G. O. (2005). The Acid Test: Does upper secondary EFL instruction effectively prepare Norwegian students for the reading of English textbooks at colleges and universities? PhD thesis, University of Oslo, Norway.

Hellekjær, G. O. (2008). A case for improved reading instruction for academic English reading proficiency. Acta Didactica Norge, 2(1), Art. 3.

Hellekjær, G. O. (2009). Academic English reading proficiency at the university level: A Norwegian case study. Reading in a Foreign Language, 21(1), 198-222.

Hellekjær, G. O. (2012). Fra Reform 94 til Kunnskapsløftet: en sammenligning av leseferdigheter på engelsk blant avgangselever i den videregående skolen i 2002 og 2011 [From Reform 94 to The Knowledge Promotion: a comparison of literacy skills in English among upper secondary school graduates in 2002 and 2011]. In T. N. Hopfenbeck, M. Kjærnsli, \& R. V. Olsen (Eds.), Kvalitet i norsk skole: Internasjonale og nasjonale undersøkelser av læringsutbytte og undervisning [Quality in the Norwegian School: International and national studies of learning outcomes and teaching] (pp. 153-171). Oslo: Universitetsforlaget.

Huang, J., \& Nisbet, D. (2012). Training adult ESL learners in metacognitive reading strategies. Journal of Adult Education, 41(1), 1-7.

Jiménez, R. T., García, G. E., \& Pearson, P. D. (1995). Three children, two languages, and strategic reading: Case studies in bilingual/monolingual reading. American Educational Research Journal, 32(1), 67-97.

Karbalaee Kamran, S. (2012). Does reading strategy use predict and correlate with reading achievement of EFL learners? International Journal of Research Studies in Language Learning, 2(2), 29-38.

Kjærnsli, M., Lie, S., Olsen, R. V., \& Roe, A. (2007). Tid for tunge løft: norske elevers kompetanse i naturfag, lesing og matematikk i PISA 2006 [Time for big efforts: Norwegian students' competence in science, reading, and mathematics in PISA 2006]. Oslo, Norway: Universitetsforlaget.

Koda, K. (2007). Reading and language learning: Crosslinguistic constraints on second language reading development. Language Learning, 57(1), 1-44.

Kong, A. (2006). Connections between L1 and L2 readings: Reading strategies used by four Chinese adult readers. The Reading Matrix, 6(2), 19-45.

Mahan, K. R., \& Brevik, L. M. (2013). I can English very good: engelske ordfeil blant norske elever og studenter [I can English very good: English word errors among Norwegian pupils and students]. Bedre Skole, 3, 34-39.

Malcolm, D. (2009). Reading strategy awareness of Arabic-speaking medical students studying in English. System, 37(4), 640-651.

Mokhtari, K., \& Reichard, C. (2002). Assessing students' metacognitive awareness of reading strategies. Journal of educational psychology, 94(2), 249-259.

Mokhtari, K., \& Reichard, C. (2004). Investigating the strategic reading processes of first and second language readers in two different cultural contexts. System, 32(3), 379-394.

Mokhtari, K., \& Reichard, C. (2008). The impact of reading purpose on the use of reading strategies. In K. Mokhtari \& R. Sheorey (Eds.), Reading strategies of first- and secondlanguage learners: See how they read (pp. 85-97). Norwood, MA: Christopher-Gordon Pub.

Mokhtari, K., \& Sheorey, R. (2002). Measuring ESL students' awareness of reading strategies. Journal of Developmental Education, 25(3), 2-10.

Olsen, S. (1999). Errors and compensatory strategies: a study of grammar and vocabulary in texts written by Norwegian learners of English. System, 27, 191-205.

Paris, S. G., \& Jacobs, J. E. (1984). The benefits of informed instruction for children's reading awareness and comprehension skills. Child Development, 55(6), 2083-2093. 
PISA (2016). PISA 2015 Results (Volume I). Retrieved from http://www.oecd.org/pisa/

Royer, J. M., \& Carlo, M. S. (1991). Transfer of comprehension skills from native to second language. Journal of Reading, 34(6), 450-455.

Shaw, P., \& McMillion, A. (2008). Proficiency effects and compensation in advanced secondlanguage reading. Nordic Journal of English Studies, 7(3), 123-143.

Sheorey, R., \& Mokhtari, K. (2001). Differences in the metacognitive awareness of reading strategies among native and non-native readers. System, 29(4), 431-449.

Utdanningsdirektoratet (2013). Curricula in English. Retrieved from http://www.udir.no/Stottemeny/English/Curriculum-in-English/

Zhang, L. J., \& Wu, A. (2009). Chinese senior high school EFL students' metacognitive awareness and reading-strategy use. Reading in a Foreign Language, 21(1), 37-59.

\section{Appendix A}

(This is the version of the questionnaire which asks about reading in English.)

\section{Survey of Reading Strategies in English}

Hello and welcome to this survey about reading strategy use!

Thanks so much for being willing to help out with research about studying in a second language. Participation in this study involves answering some questions about strategies you use when reading for university and also some background questions. The survey takes around 10 minutes to complete and all data will be treated confidentially.

This research is being conducted as part of a $\mathrm{PhD}$ project at NTNU and has been registered with the Data Protection Official for Research, NSD - The Norwegian Centre for Research Data. The project is due to be completed by the 30th June 2019.

If you have any questions about this research, please contact the main researcher, Nicole Busby (nicole.busby@ntnu.no).

Your participation in this survey is completely voluntary and you can stop any time you like. Thanks again! :D

The purpose of this study is to collect information about the various techniques you use when you read ACADEMIC materials in ENGLISH (e.g. reading textbooks for homework or examinations, reading journal articles, etc).

All of the items on this page [the next pages] refer to your reading of university-related academic materials (such as textbooks and academic articles, not newspapers or magazines). Select the answer which best reflects how often you use each of these techniques for your English readings.

Each statement is followed by five numbers, 1, 2, 3, 4, and 5 and each number means the following:

' 1 ' means that 'I never or almost never do this'

'2' means that 'I do this only occasionally'

' 3 ' means that 'I sometimes do this' (About $50 \%$ of the time)

'4' means that 'I usually do this'

'5' means that 'I always or almost always do this'

After reading each statement, select the number which applies to you. Note that there are no right or wrong responses to any of the questions on this survey. 
Click the 'next' button to begin the survey.

Please note that your response will only be counted if you complete the survey.

I have a purpose in mind when I read
I take notes while reading to help me
understand what I read
I think about what I know to help me
understand what I read
I take an overall view of the text to see what it
is about before reading it
When text becomes difficult, I read aloud to
help me understand what I read
I think about whether the content of the text fits
my reading purpose
I read slowly and carefully to make sure I
understand what I am reading
I review the text first by noting its
characteristics like length and organization
I try to get back on track when I lose
concentration
I underline or circle information in the text to
help me remember it

I adjust my reading speed according to what I
am reading
When reading, I decide what to read closely and
what to ignore
I use reference materials (e.g. a dictionary) to
help me understand what I read
When text becomes difficult, I pay closer
attention to what I am reading
I use the tables, figures and pictures in the text
to increase my understanding
I stop from time to time and think about what I
am reading
I use context clues to help me better
understand what I am reading
I paraphrase (restate ideas in my own words) to
better understand what I read
I try to picture or visualize information to help
remember what I read
I use typographical features like bold face and
italics to identify key information




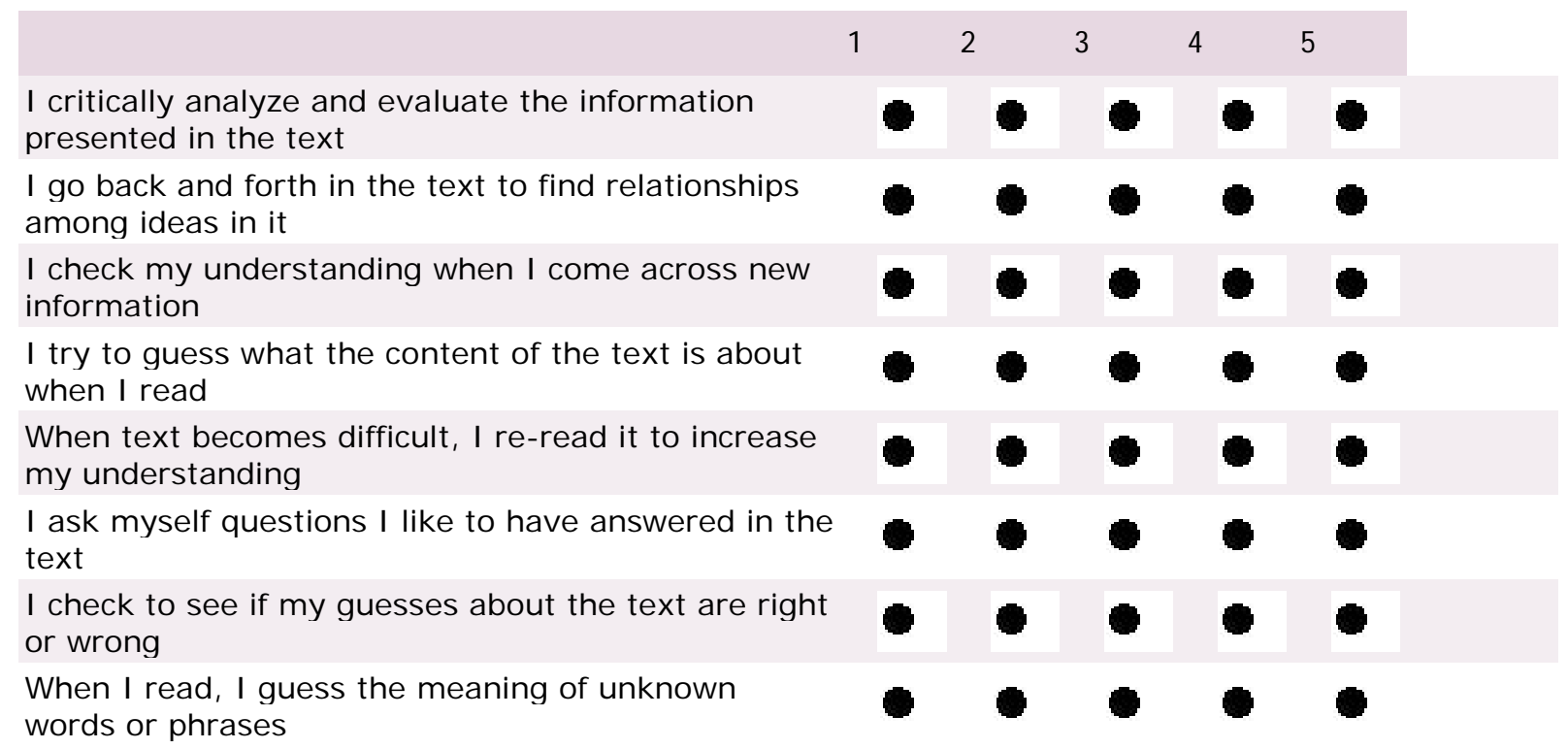

If English is your native language, please select 'not applicable' for the next two questions
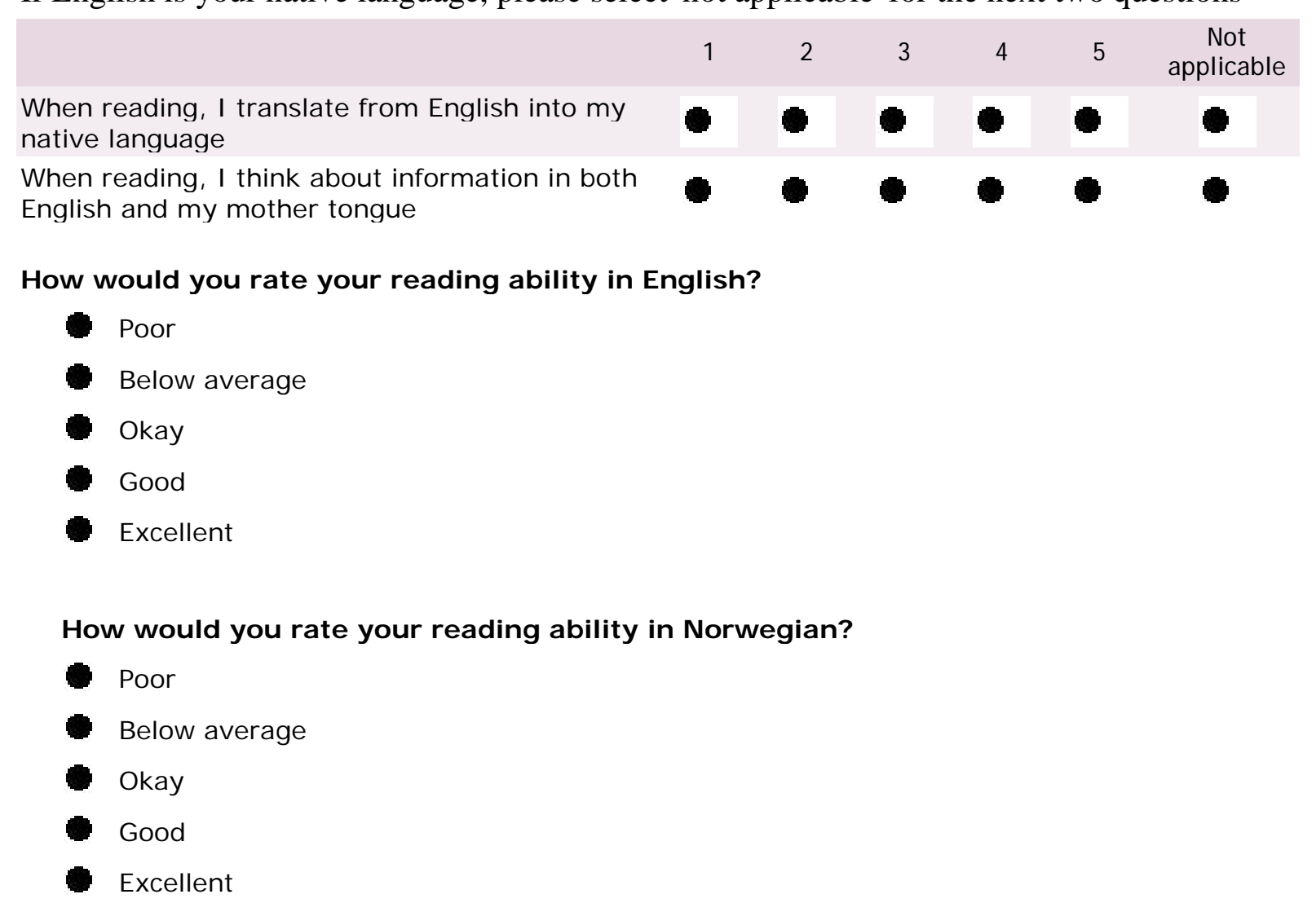

How quickly do you feel that you read course materials in English?

- Very slowly

- Quite slowly

- Average

- Quite quickly

- Very quickly 
How quickly do you feel that you read course materials in Norwegian?

- Very slowly

Quite slowly

- Average

Quite quickly

- Very quickly

How easy do you find it to understand course material in English?

- Many things are difficult to understand

- Some things are difficult to understand

- Some things are easy, some are harder

- Most things are easy to understand

- Everything is easy to understand

How easy do you find it to understand course material in Norwegian?

- Many things are difficult to understand

- Some things are difficult to understand

- Some things are easy, some are harder

- Most things are easy to understand

- Everything is easy to understand

What is your native language? (you can select more than one if you consider yourself to have more than one native language)

Г Norwegian

$\Gamma$ English

- Other
Gender
- Female
- Male
- Other
Age
- under 18
C $18-20$
- 21-23
C 24-26
- $27-29$
- 30 or over 
How many courses ( 7.5 credits) have you completed at university?

- None (this is my first semester)

1 - 4 courses ( 7.5 - 30 credits)

5 - 8 courses ( 37.5 - 60 credits)

- 9 - 16 courses (67.5 - 120 credits) (one - two years of full-time study equivalent)

- 17 - 24 courses (two - three years of full-time study equivalent)

- 25 - 32 courses (three - four years of full-time study equivalent)

- more than 32 courses (four years of full-time study equivalent)

\section{What grades do you usually get at university?}

- mostly As

- mostly Bs

- mostly Cs

- mostly Ds

- mostly Es

mostly Fs

- I don't have any grades from university yet (this is my first semester)

How many of your textbooks and required course readings are in English?

- None

- $1-25 \%$

$25-50 \%$

$50-75 \%$

- $75-100 \%$

\section{Which of the following best describes your field of study?}

- Psychology

- Geography

- Social anthropology

- Archaeology

- Sign language/interpreting

Other, please specify

Is there anything you would like to add? (optional) 


\section{Appendix B}

Reading strategies reported being used most (top) and least (bottom) frequently when reading in Norwegian (L1) and English (L2)

\begin{tabular}{|c|c|c|c|c|c|}
\hline Subscale & $\begin{array}{l}\text { Reading Strategy - } \\
\text { Norwegian }\end{array}$ & $M$ & Subscale & Reading Strategy - English & $M$ \\
\hline PROB & Adjusting reading speed & 4.11 & PROB & Adjusting reading speed & 4.19 \\
\hline PROB & Trying to stay focused & 4.04 & PROB & Trying to stay focused & 4.18 \\
\hline PROB & Paying close attention & 4.03 & PROB & Paying close attention & 4.09 \\
\hline PROB & Re-reading difficult text & 3.97 & PROB & Re-reading difficult text & 4.04 \\
\hline GLOB & Setting purpose for reading & 3.89 & GLOB & Setting purpose for reading & 3.78 \\
\hline GLOB & Using prior knowledge & 3.69 & GLOB & $\begin{array}{l}\text { Using text features (tables, } \\
\text { figures) }\end{array}$ & 3.76 \\
\hline GLOB & $\begin{array}{l}\text { Using text features (tables, } \\
\text { figures) }\end{array}$ & 3.57 & PROB & Slow and careful reading & 3.62 \\
\hline GLOB & Deciding what to read & 3.54 & GLOB & Using prior knowledge & 3.60 \\
\hline SUPP & Taking notes & 3.52 & GLOB & Deciding what to read & 3.59 \\
\hline GLOB & $\begin{array}{l}\text { Checking how text fits } \\
\text { purpose }\end{array}$ & 3.41 & SUPP & Taking notes & 3.58 \\
\hline PROB & Slow and careful reading & 3.38 & SUPP & Underlining, circling information & 3.38 \\
\hline GLOB & $\begin{array}{l}\text { Checking understanding of } \\
\text { new information }\end{array}$ & 3.35 & GLOB & $\begin{array}{l}\text { Checking understanding of new } \\
\text { information }\end{array}$ & 3.37 \\
\hline SUPP & $\begin{array}{l}\text { Underlining, circling } \\
\text { information }\end{array}$ & 3.34 & GLOB & Checking how text fits purpose & 3.36 \\
\hline GLOB & Using context clues & 3.20 & SUPP & $\begin{array}{l}\text { Using reference materials (e.g. } \\
\text { dictionary) }\end{array}$ & 3.35 \\
\hline GLOB & Preview text before reading & 3.19 & GLOB & Using context clues & 3.27 \\
\hline GLOB & Noting text characteristics & 3.13 & SUPP & Paraphrasing & 3.24 \\
\hline GLOB & Critically evaluating & 3.09 & GLOB & Noting text characteristics & 3.18 \\
\hline SUPP & Paraphrasing & 3.08 & PROB & $\begin{array}{l}\text { Pausing and thinking about } \\
\text { reading }\end{array}$ & 3.16 \\
\hline GLOB & Using typographical features & 3.06 & GLOB & Guessing text meaning & 3.15 \\
\hline PROB & Visualising information & 3.04 & PROB & $\begin{array}{l}\text { Guessing meaning of difficult } \\
\text { words }\end{array}$ & 3.14 \\
\hline GLOB & Guessing text meaning & 3.03 & GLOB & Preview text before reading & 3.09 \\
\hline PROB & $\begin{array}{l}\text { Pausing and thinking about } \\
\text { reading }\end{array}$ & 3.01 & GLOB & Critically evaluating & 3.09 \\
\hline PROB & $\begin{array}{l}\text { Guessing meaning of } \\
\text { difficult words }\end{array}$ & 2.97 & PROB & Visualising information & 3.04 \\
\hline SUPP & $\begin{array}{l}\text { Using reference materials } \\
\text { (e.g. dictionary) }\end{array}$ & 2.94 & SUPP & Going back and forth in the text & 2.92 \\
\hline SUPP & $\begin{array}{l}\text { Going back and forth in the } \\
\text { text }\end{array}$ & 2.90 & GLOB & Using typographical features & 2.89 \\
\hline SUPP & Reading aloud & 2.40 & SUPP & Asking myself questions & 2.48 \\
\hline GLOB & Confirming predictions & 2.38 & SUPP & Reading aloud & 2.47 \\
\hline SUPP & Asking myself questions & 2.38 & GLOB & Confirming predictions & 2.41 \\
\hline
\end{tabular}

Note: GLOB = Global reading strategies, SUPP = Support reading strategies, $\mathrm{PROB}=$ Problem Solving strategies 